\title{
The Sharing Economy in the Context of Sustainable Development and Social Responsibility: The Example of the Czech Republic
}

\author{
Martina Jelinkova, Libena Tetrevova *(D), Jan Vavra (D) and Simona Munzarova (D)
}

check for updates

Citation: Jelinkova, M.; Tetrevova, L.; Vavra, J.; Munzarova, S. The Sharing Economy in the Context of Sustainable Development and Social Responsibility: The Example of the Czech Republic. Sustainability 2021, 13, 9886. https:// doi.org/10.3390/su13179886

Academic Editor: Antonio Boggia

Received: 6 August 2021

Accepted: 29 August 2021

Published: 2 September 2021

Publisher's Note: MDPI stays neutral with regard to jurisdictional claims in published maps and institutional affiliations.

Copyright: (c) 2021 by the authors. Licensee MDPI, Basel, Switzerland. This article is an open access article distributed under the terms and conditions of the Creative Commons Attribution (CC BY) license (https:// creativecommons.org/licenses/by/ $4.0 /)$.
Department of Economy and Management of Chemical and Food Industries, Faculty of Chemical Technology, University of Pardubice, Studentska 95, 53210 Pardubice, Czech Republic; martina.jelinkova@upce.cz (M.J.); jan.vavra@upce.cz (J.V.); simona.munzarova@upce.cz (S.M.)

* Correspondence: libena.tetrevova@upce.cz; Tel.: +420-46-6036661

\begin{abstract}
The rapid development of the sharing economy that has been registered in recent years is caused by a number of factors. The increasingly pronounced effort on the part of all economic entities to contribute towards sustainable development through the application of socially responsible behavior is deemed to be a key factor. The objective of the article is to analyze and evaluate the attitudes of customers towards the benefits of the sharing economy in the field of economic, social, and environmental responsibility using the example of a small post-communist economy-the Czech Republic. Primary data were obtained on the basis of a questionnaire survey. This was elaborated using descriptive and inferential statistics tools. The study that was performed shows that the majority of customers regard sharing as a source of benefits in the field of economic, social, and environmental responsibility, whereas in a complex sense, they perceive these benefits to be equal. Women perceive the investigated benefits of sharing with regard to environmental responsibility as more important compared to men. In comparison with the older generation, the younger generation perceives selected benefits of sharing as more important in all three investigated areas of responsibility. People with a higher education perceive selected benefits of sharing with regard to economic responsibility as more important compared to people with a lower level of education. The article provides original insights into the perception of the benefits of sharing for sustainable development by actors in the sharing economy and is a source of knowledge about their motivations for both policymakers and managers of companies involved in the sharing economy.
\end{abstract}

Keywords: sharing economy; social responsibility; sustainability; sustainable development

\section{Introduction}

The sharing economy, based on sharing of unused assets [1-3], represents a controversial phenomenon [4]. This phenomenon has been experiencing an unprecedented boom over the past decade [5], in particular thanks to the development of digital platforms and other large-scale mediating technologies [6]. The sharing economy is successfully developing in various sectors, even on an international level [7]. Over time, all types of economic entities have started to participate in sharing-consumers [8], enterprises [8,9], universities [10], governments [11,12], and even non-profit organizations [13]. Several motives exist for their participation in the sharing economy [14]. The original [15] and key $[13,16]$ motive is deemed to be an effort to contribute towards sustainable development. This opinion is also supported by data from the European Union (EU), which shows that the reason for participation in the sharing economy for $51 \%$ of people living in EU28 countries is precisely the "more sustainable and efficient use of available assets" [17]. In the given context, Heinrichs [18] stated that the sharing economy is "a potential new pathway to sustainability". 
Sustainable development is based on three integral responsibilities-social responsibility, environmental responsibility, and economic responsibility, the so-called triple bottom line $[19,20]$. This concerns the conventional fields or pillars of social responsibility, the so-called 3Ps-people, planet, and profit [21]. Sustainable development has both a macroeconomic and a microeconomic dimension [22,23]. From a macroeconomic point of view, attention is focused on the sustainable development of national economies [23]. From a microeconomic point of view, attention is focused in particular on the sustainability of individual enterprises [23]. However, in our opinion, the microeconomic dimension also includes sustainability from the point of view of individual citizens (consumers), public institutions, and organizations or non-profit organizations.

Sharing has the potential to contribute towards sustainable development from the point of view of economic, social, and environmental responsibility [24]. From the point of view of economic responsibility, sharing itself can be seen as a tool for the creation of innovation and ensuring the sustainability of products. Sharing also contributes towards strengthening supplier-customer relations, for example, through sharing means of transport such as trucks and their cargo capacity, sharing storage space, sharing information about deliveries/orders, sharing business contacts and references, or sharing data about consumer opinions or cooperative advertising, which subsequently has a positive social multiplier effect. It also contributes towards strengthening customer relations, for example, thanks to sharing expertise. As far as the field of social responsibility is concerned, sharing jobs, sharing accommodation, carsharing, shared company catering, or shared care for the household can, for example, contribute towards strengthening social responsibility and can, among other things, represent attractive employee benefits. Charitable sharing also plays an important role in this field. As regards environmental responsibility, sharing vehicles for example, or sharing machinery, equipment, and materials, contributes significantly towards reducing the consumption of resources, reducing emissions, and preventing waste.

In order to exploit the sustainability potential of the sharing economy, attention must be focused on research into topics such as "empirical analysis and assessment of practices concerning the economic, social, and environmental effects of the sharing economy" [18]. The fact is that the sharing economy model is developed to a different extent in individual countries. An interesting finding is that sharing is preferred in emerging economies as opposed to developed economies [7]. The attitudes of stakeholders towards this phenomenon also differs from the point of view of individual demographic characteristics [17,25]. However, research to date has not addressed the attitudes of the actors participating in the sharing economy as regards its impact on sustainable development. On the basis of the aforementioned, it would seem expedient to investigate the attitudes of individual citizens, who could act as people inquiring about services or goods and also as people offering such things, towards the benefits of sharing as regards sustainable development. The objective of the article is to analyze and evaluate the attitudes of respondents towards the benefits of the sharing economy in the field of economic, social, and environmental responsibility using the example of a small post-communist economy-the Czech Republic. Primary data obtained on the basis of the questionnaire survey were processed using descriptive and inferential statistics tools.

The later parts of the text are structured as follows. The basic theoretical background of the topic under investigation is explained in the Section 2 on the basis of a systematic literature review. Specifically, theoretical approaches to defining and conceptualizing the relationship between sustainable development, social responsibility, and the sharing economy are presented there. Attention is also focused on mapping alternative motives for sharing and attitudes towards them. In the Section 3, an explanation is provided of the research methodology and a specification is provided of the method of collection of primary data and the methods of statistical processing. The findings of the study - an evaluation of the attitudes of Czech citizens towards the economic, social, and environmental benefits of the sharing economy, i.e., in terms of the triple bottom line-are presented in Section 4 with regard to basic demographic characteristics (gender, age, and education). Both 
macroeconomic and microeconomic concepts of benefits were taken into consideration within the framework of the applied methodology. Both macro-level benefits to sustainable development, i.e., from the perspective of the national economy, and micro-level benefits, specifically from the perspective of customers, were taken into consideration. In the Section 5, the findings of the research are discussed and summarized. The findings that were ascertained can be used by policymakers, business managers, civil society actors, and other stakeholders to shape and develop the sharing economy in a sustainable manner.

\section{Literature Review and Hypotheses}

\subsection{Sustainable Development, Social Responsibility, and the Sharing Economy}

The concept of sustainable development has different meanings as conceived by different authors [26]. According to the original definition by the World Commission on Environment and Development (WCED), sustainable development is understood to mean "development that meets the needs of the present without compromising the ability of future generations to meet their own needs" [27]. The original environmentally defined concept has been extended to include the equally important social pillar in the form of the triple bottom line [19]. Sustainable development is also perceived of in this sense in the Millennium Declaration [28], which defines economic development, social development, and environmental protection. The current shift in the concept places greater emphasis on the circular or shared use of resources $[29,30]$ and looking at the social dimension from the level of politics and culture [31]. Klarin [26] summed up the three key elements of the concept of sustainable development: "(1) the concept of development (socio-economic development in line with ecological constraints), (2) the concept of needs (redistribution of resources to ensure the quality of life for all) and (3) the concept of future generations (the possibility of a long-term usage of resources to ensure the necessary quality of life for future generations)".

In an effort to define the essence of sustainability, the determination of the goals, criteria, and indicators of sustainable development was from the very start perceived as a fundamental and essential process. The first requirements were proclaimed in Chapter 40 of Agenda 21 [32]. After five years of efforts, the CSD Work Programme on Indicators of Sustainable Development presented the first proposals for goals and indicators in 2000 [33]. Subsequent long-term development and testing did not bear fruit in the form of comprehensive formulation of the Indicators of Sustainable Development until 2013 [34]. The tendency to further specify areas of sustainable development led to the formulation of the current 17 goals (Sustainable Development Goals-SDGs) with more than 100 indicators to measure them in the form of a comprehensive UN program for the 2015-2030 period [35].

The definition of sustainable development can at present be grasped precisely via the determined SDGs and problem areas that these goals cover. Each of the 17 goals represents an area of sustainable development for which it is necessary to formulate a transformation strategy for the most important stakeholders: governments, civil society, science, and business [36,37]. More and more interest is being taken in issues, in particular in social topics relating to poverty [38], equality and inequality [39-41], education [42], peace, violence and justice [43], dignified work [44], work-life balance [45], and responsibility [46], a fact that is illustrated by the continuing growth in importance of the social aspects of sustainability.

With the strengthening of the social aspects of sustainability, the concept of sustainable development is increasingly linked to the concept of social responsibility of entrepreneurs, enterprises and corporations, governments, public institutions and organizations, consumers, and other stakeholders. However, the definition of the relationship between sustainability and responsibility is conceived differently by different authors.

Sustainable development is, for example, perceived as the basis for the social responsibility of economic entities [47]. The opposite point of view is offered by the assumption that socially responsible behavior is regarded as a condition for achieving sustainable development and the sustainability of economic entities [48]. However, the opinion that 
the concepts of sustainable development and social responsibility are basically the same does not prevail [47]. This opinion seems logical in view of the fact that both concepts are built on the same pillars-economic, social, and environmental.

As regards the concept of social responsibility, this was in the beginning associated with the behavior of entrepreneurs [49]. Over time, as a result of the development of commercial activities, it started to be associated with the behavior of enterprises [50]. In the end, it was extended to include the behavior of all economic entities, i.e., also public institutions and organizations, non-profit organizations, and individuals (consumers) [51]. The attention of the authors is devoted to the greatest extent to the issue of corporate social responsibility (CSR) [52]. However, modification of the concept of CSR also led to the creation of concepts such as MSR (municipal social responsibility) $[53,54]$ or USR (university social responsibility) [55-57].

From the time of its initial definition [49], the term "social responsibility" was met with ambiguous reception, even criticism [58]. Elkington introduced the concept in the wider awareness by formulating three areas of responsibility-people, profit, and planet (the 3Ps) [19]. Over the past few decades, social responsibility has been regarded as a desired pattern of ethical and moral behavior of individuals and organizations and the intention to contribute towards the well-being of society or economic entities-made up of various communities and stakeholders [59]. The principles of social responsibility have been enshrined in the form of the ISO 26000:2010 standard, where formulation of the seven core subjects of social responsibility is provided: organizational governance, human rights, labor practices, environment, fair operating practices, consumer issues, and community involvement and development [60]. The standard provides instructions on how organizations can (in line with the SDGs) operate in an ethical and transparent manner that contributes towards sustainability, taking into consideration the expectations of the stakeholders, the applicable laws, and international standards of behavior [61]. Increasing the social performance of an enterprise while at the same time preserving its competitiveness and growing environmental performance is a demanding and costly business and requires a proactive approach in the field of sustainable innovations [20]. Nevertheless, it must be pursued in the context of comprehensive and interconnected social, environmental, and economic issues (triple bottom line) [62].

Socially responsible behavior can be applied in the abovementioned areas through a variety of activities $[63,64]$. Sharing can be considered to be a rapidly growing activity that is gaining importance worldwide. Sharing tangible and intangible assets is a traditional form of utilization of resources. Nevertheless, the rise of communication and digital platforms has made occasional sharing a controlled, efficient, and competitive industry [65]. The sharing economy in the form of prioritizing access to tangible and intangible resources and products through sharing via digital platforms over ownership [66] is characterized by a high potential for saving resources and other tangible assets (environmental aspects) [67], as well as by greater utilization of intangible assets such as talent, knowledge, time, and experience (social aspects) [68]. The ability to streamline the utilization of resources and products (in line with the SDGs) supports the sustainability of economic entities and also represents one of the main benefits of the so-called circular economy [69]. The complexity of the whole system of the sharing economy has a subsequent impact on a wide range of stakeholders within the meaning of sustainability and responsibility [70]. The close relationship between sustainable development, social responsibility, and the sharing economy was, for example, declared by Leung et al. [4]. Hossain [71] also drew attention to the relationship between the sharing economy and sustainability, in whose opinion the sharing economy "emphasizes the sharing of underutilized assets in ways that improve efficiency and sustainability". Changes are also evident in the concept of CSR when it is desirable for CSR activities to help create value with cross-sector collaboration and sharing, something that directly supports sustainability [72]. Last but not least, mention is made of the importance of digitization and the linking of CSR activities to communication 
platforms used for the sharing economy, which also raises ethical questions as to whether responsibility in the shared economy must/can be shared [73].

\subsection{The Sharing Economy in the Context of Motives and Attitudes}

Many motives exist for participation in the sharing economy, whereas authors (e.g., [74-76]) have discussed both extrinsic and intrinsic motivation. Wilhelms et al. [77] identified four overarching motives for participation in the sharing economy, these being economic interest, quality of life, helping others, and sustainability. Hamari et al. [75] also mentioned four categories of motives for participation in sharing, including sustainability. They ranked enjoyment, reputation, and economic benefits as the remaining three motives. Joo [76] also regards sustainability to be a motive for sharing. He included it in the category "social value", regarding cost savings, time savings, and convenience as other motives. An alternative view of motives for sharing was offered by Grybaite and Stankevičienè [78]. In their concept, motives for sharing coincide with the pillars of sustainable development and social responsibility, as they regard them to be economic, environmental, and social benefits. Economic, environmental, and social motives for sharing were also distinguished by Hallem et al. [79], whose concept of social motives does however differ from the other authors. This is to say that they regard social motives to be the benefits of sharing in the form of fun and experiences.

According to Barnes and Mattsson [80], it is precisely sustainability combined with economic, social, and environmental benefits that is regarded as the key driving force behind the development of sharing. This opinion is also shared by Geissinger et al. [81], who regard sustainability to be the original motive behind sharing. This is also evident from the results of the Eurobarometer study, according to which sustainability is one of the key motives for participation by providers in the sharing economy in EU28 countries [17]. The importance of sustainability or social responsibility as a motive for participation in the sharing economy is also evident from a study conducted by Andreotti et al. [25] in 11 Western European countries and Poland. The study shows that from the point of view of providers, this motive ranks second after financial benefit and, in the case of consumers, this motive ranks third after financial benefit and fun. Leung et al. [4] also believe that the development of the sharing economy is associated with economic, socio-cultural, and environmental benefits. In their opinion, the economic benefits of the sharing economy are constituted by creating new jobs and income, boosting the local economy, addressing inequality, and reducing inefficiency. They consider that increasing social well-being by cultivating trust and strengthening social connections and improving quality of life by making products and services better quality and more affordable to be socio-cultural benefits. In their opinion, environmental benefits include optimization of the utilization of resources and assets and help to address issues like transportation systems and the availability of environmental standards targeting a more sustainable world. In this context, Geissinger et al. [81] drew attention to the fact that the contribution towards sustainability differs significantly from the point of view of the individual segments of the sharing economy. We can therefore formulate hypothesis $\mathrm{H} 1$.

Hypothesis 1 (H1). From the point of view of the majority of customers, sharing is a source of benefits not only in the field of economic responsibility, but also social and environmental responsibility.

However, economic, social, and environmental responsibility as motives plays different roles in the development of the sharing economy. According to Barnes and Mattsson [80], the primary role is played by economic responsibility, followed by social responsibility. Environmental responsibility is therefore of least importance. Hallem et al. [79] also emphasized the dominant role played by economic factors. This was also confirmed by a study performed by Grybaite and Stankevičienè [78] in Lithuania. On the contrary, Geissinger et al. [81] attributed a primary role to environmental responsibility. The results of a study performed by Ipsos [82] in the Czech Republic in 2020 are also testament to the fundamental role played by environmental responsibility. This study shows that customers 
generally regard environmental responsibility to be the most important within the framework of fulfilment of the concept of CSR. It is of fundamental importance to them both when purchasing products and also in terms of their own socially responsible behavior. In this study, $70 \%$ of respondents stated that they would be willing to pay extra for a product that is environmentally friendly. A total of $68 \%$ of respondents declared that they behave in a considerate manner towards nature and the environment within the framework of their own personal social responsibility. The question therefore is whether economic or environmental motives for sharing prevail. In view of the social psychological models of consumer behavior in the form of rational choice models [83], it can be assumed that a greater role is played by the economic dimension. According to this theory, entities do after all behave rationally, in line with their personal preferences. We generally assume that individuals behave egoistically and try to maximize their own benefit, whereas economic benefit plays a crucial role here. This idea is also supported by the manner in which enterprises communicate their socially responsible activities. In line with the stakeholder theory [84], enterprises place the greatest emphasis on communication of economically responsible activities [85], with the exception of certain environmentally sensitive enterprises [86]. According to this theory, a prerequisite for the success of a company is respect for the needs and interests of those who can influence or are influenced by achievement of the organization's goals. We can therefore formulate Hypothesis H2.

Hypothesis 2 (H2). Customers regard benefits in the field of economic responsibility to be the most important benefits of sharing.

Perception of the importance of the motives for/benefits of sharing in the form of social responsibility differs from the point of view of the gender, age, and education of respondents [25,79]. According to Andreotti et al. [25], the importance of this motive is emphasized in particular by women compared to men. This is perceived as a key motive from the point of view of the younger generation under the age of 34 [25]. Its importance decreases with increasing age [25]. It would be appropriate to add in the given context that the actual phenomenon of sharing in itself is perceived as a phenomenon intended especially for young people [87]. Young people are more positive towards this [88], with generations $\mathrm{Y}$ and $\mathrm{Z}$ being particularly open to the concept [89]. The importance of the benefit of sharing for the fulfilment of social responsibility grows as the level of education achieved by respondents increases [25]. People with a higher level of education are generally more open to sharing [89].

On the basis of the aforementioned, it is possible formulate the following hypotheses:

Hypothesis 3 (H3). Women perceive the economic, social, and environmental benefits of sharing as more important compared to men.

Hypothesis 4 (H4). The younger generation perceives the economic, social, and environmental benefits of sharing as more important compared to the older generation.

Hypothesis 5 (H5). People with a higher level of education perceive the economic, social, and environmental benefits of sharing as more important compared to people with a lower level of education.

\section{Materials and Methods}

Elaboration of the study is based on the assumption confirmed above that socially responsible behavior towards sustainable development can be applied by all economic entities, including individual citizens. People can engage in socially responsible activities as consumers, but also as citizens of the given country. Identifying their attitudes towards alternative activities that could contribute significantly towards achieving sustainable development goals seems to be a key factor in positively shaping the concept of sustainable development [35]. One such activity is sharing, applying the model of the sharing economy in general. As is evident from the aforementioned, sharing is associated with economic, 
social, and environmental benefits (e.g., [4]). Our objective was to analyze and evaluate the attitudes of individual citizens towards the benefits of the sharing economy in the fields of economic, social, and environmental responsibility using the example of a small postcommunist economy - the Czech Republic. The reason for the focus on the Czech Republic was, above all, the fact that it concerns a post-communist economy that in general exhibits a higher degree of participation in sharing [7]. Another reason was the controversial perception of the sharing economy from the point of view of citizens of the Czech Republic, which appeared in particular as a consequence of its insufficient regulation [90]. Last but not least, the reason for our focus on this country is knowledge of the local environment on the part of the authors. The basic concept of the research is evident in Figure 1.

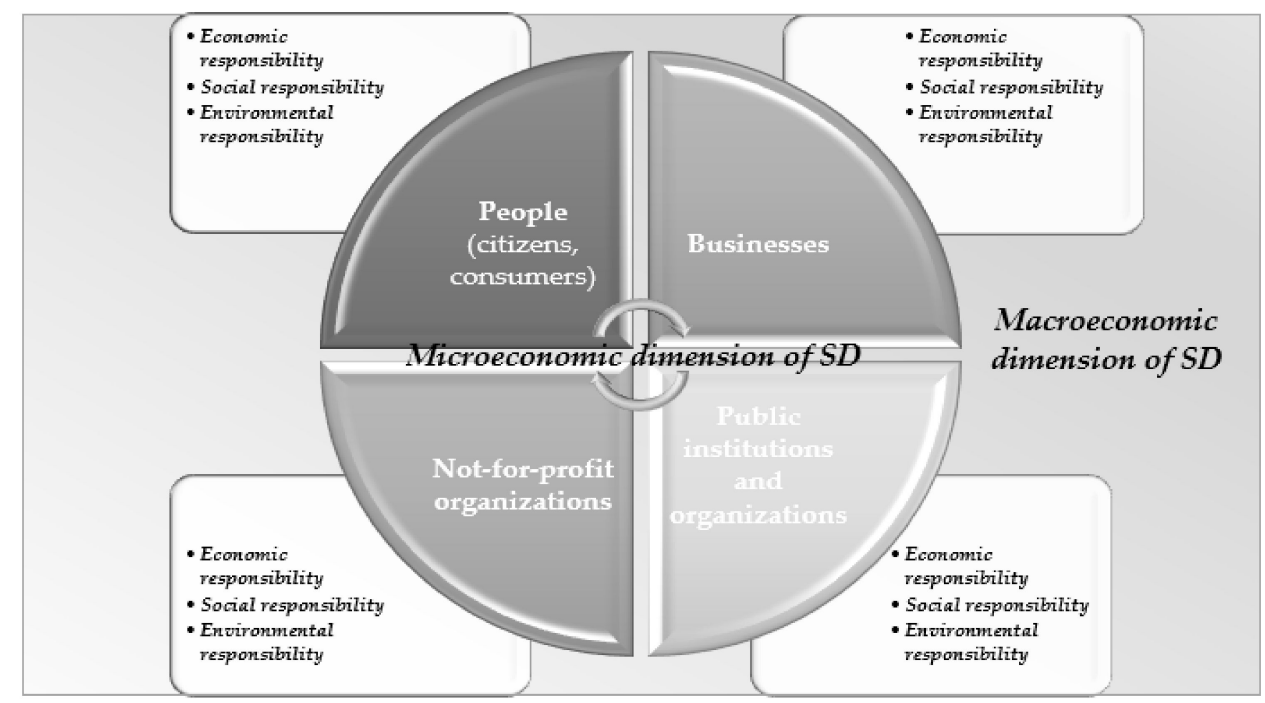

Figure 1. The basic concept of the research.

The study presented here is based on the elaboration of systematic literary research [91,92] on the topic of sustainable development, social responsibility of economic entities, the sharing economy, and their mutual relationship. With regard to relevance and topicality, the subject of this research was articles primarily published in journals registered in the Web of Science and Scopus databases. The keywords searched for were the terms "sharing" OR "sharing economy" AND "social responsibility" AND "sustainability" OR "sustainable development." Sources of literary research were subsequently extended thanks to the application of the snowball method $[93,94]$.

Literary research was then conducted by quantitative research. The reason for this was the advantages associated with this method of research. That is to say that it allows for easy processing of a large quantity of data, simple interpretation of results, and also the comparison of time and between categories [95]. It can be easily replicated and the results compared to those of similar studies [96]. Another advantage is the fact that the results can be generalized when a representative selection of respondents is chosen [97]. As opposed to qualitative research, quantitative research ensures greater precision and objectivity of the results that are obtained and eliminates bias [98]. It can therefore be regarded as an appropriate method to finalize results and refute or prove the research hypotheses.

Within the framework of the quantitative research presented, analysis and evaluation were performed on the attitudes of individual citizens towards 10 specific statements expressing the benefits of the sharing economy in the field of economic, social, and environmental responsibility. The concept of the triple bottom line was chosen because it concerns the conventional and most widespread concept of social responsibility and sustainable development. Specifically, the survey focused on people's attitudes towards four statements relating to economic responsibility, four statements relating to social responsibility, and two statements relating to environmental responsibility. These are statements that cover both the microeconomic and macroeconomic dimensions of sustainable develop- 
ment. A list of statements, including their categorization, can be found in Table 1 . Their selection was based on the list of socially responsible activities contained in the method of communication of economic, environmental, ethical, social, and philanthropic activities (CE3SPA) [85,99]. Here, we took our starting point from the assumption of analogy in the application of socially responsible behavior by individual economic entities. The reason for the choice of the CE3SPA method was the fact that it is a method that comprehensively addresses potential socially responsible activities and respects modern communication trends. Last but not least, the reason for choice of this method was the many years of positive experience by the authors of the article with the application of this method.

Table 1. Evaluated statements and their basic characteristics.

\begin{tabular}{|c|c|c|c|}
\hline & Statements & Responsibility & Dimension \\
\hline 1. & The sharing economy is beneficial to the economy of the country. & Economic & MAE \\
\hline 2. & The sharing economy is a way to ensure more efficient utilization of resources. & Economic & MAE \\
\hline 3. & Use of services in the sharing economy saves users a significant amount of money. & Economic & MIE \\
\hline 4. & The sharing economy may be an interesting source of income for providers of assets. & Economic & MIE \\
\hline 5. & The sharing economy contributes towards a greater level of employment and creates new jobs. & Social & MAE \\
\hline 6. & Participation in the sharing economy simplifies the work-life balance. & Social & MIE \\
\hline 7. & Use of services in the sharing economy is a source of unusual experiences. & Social & MIE \\
\hline 8. & Sharing via platforms saves users time. & Social & MIE \\
\hline 9. & Sharing is environmentally friendly thanks to saving resources. & Environmental & MAE \\
\hline 10. & Sharing limits the production of waste. & Environmental & MAE \\
\hline
\end{tabular}

Legend: MAE = macroeconomic, MIE = microeconomic.

The attitudes of the respondents to the abovementioned statements were ascertained during primary research using computer-assisted web interviewing (CAWI), which represents a modern method of collecting data via questionnaires provided via the internet [100]. This method was chosen in view of the fact that it is a relatively cheap, fast, and reliable method, which makes it possible to reach a large and dispersed group of respondents [101,102]. The electronic questionnaire was made available to respondents from September to October 2019 via the LimeSurvey application. Choosing an electronic format for the questionnaire ensured that it could be completed conveniently and completely anonymously [103], and also allowed for relatively fast and simple evaluation [104].

Quota sampling was chosen as the method of selection of respondents. This is preferred in particular in the types of sociological surveys where it is difficult to specify all of the members of the basic group (e.g., the population), but it is possible to determine basic statistical characteristics that are assumed to correlate with the variables being ascertained [105]. This is a quasi-representative method that, if performed correctly, achieves similar results to probability sampling methods [106], as the sample can be assumed to represent the entire population under investigation [107]. The economic, time, and staffing merits of this type of sampling were used [108], a method that has become one of the most widely used in sociological research due to its benefits $[109,110]$.

The selection of quota characteristics in research is not precisely determined and always depends on the judgment of the researcher. For surveys where the population as a whole is the basic research group, demographic variables such as gender, age, and education are typically used as quota characteristics [111]. The reason for this, among others, is the fact that the attitudes of the respondents very often differ within the framework of these demographic characteristics [105]. This can also be assumed in the case of our 
research. That is why age and gender were chosen as quota characteristics and the other characteristic investigated was the level of education achieved by the respondents. In view of the fact that the analysis of the data we acquired did not require a second or higher-level classification, simple quotas were sufficient, the use of which is less labor-intensive and less costly compared to cross quotas [112]. The sample according to the quota characteristics corresponds to the population structure of the Czech Republic ascertained on the website of the Czech Statistical Office (data as of 31 December 2018). Using a network of interviewers from the ranks of students at the University of Pardubice, a total of 630 respondents were contacted according to the chosen quota characteristics and asked to fill out an electronic questionnaire. A total of 614 fully completed questionnaires were received, the success rate being $98 \%$. The structure of the respondents is evident in Tables $2-4$.

Table 2. Structure of respondents by gender.

\begin{tabular}{ccc}
\hline Gender & $\mathbf{N}$ & \% \\
\hline Male & 277 & $45 \%$ \\
\hline Female & 337 & $55 \%$ \\
\hline Total & 614 & $100 \%$ \\
\hline
\end{tabular}

Table 3. Structure of respondents by age.

\begin{tabular}{ccc}
\hline Age & $\mathbf{N}$ & $\%$ \\
\hline $15-29$ years & 224 & $36 \%$ \\
\hline 30 or more years old & 390 & $64 \%$ \\
\hline Total & 614 & $100 \%$ \\
\hline
\end{tabular}

Table 4. Structure of respondents by education.

\begin{tabular}{ccc}
\hline Education & N & \% \\
\hline Primary and secondary & 455 & 74 \\
\hline Higher & 159 & 26 \\
\hline Total & 614 & $100 \%$ \\
\hline
\end{tabular}

The structure of the sample according to the quota characteristics corresponded to the structure of the Czech population $\pm 5 \%$ of the required number of respondents, which is absolutely acceptable from the point of view of this type of research [112].

The data were processed by descriptive and inferential statistics using the statistical software package IBM SPSS Statistics, version 24. First of all, the respondents' attitudes towards the benefits of the sharing economy under investigation were described via the absolute and relative frequencies of responses within the different levels of the four-point Likert scale used, offered in the interval of $1=$ strongly agree to $4=$ strongly disagree. The Likert scale we used, which is very popular for ascertaining attitudes, did not include a neutral value (neither-nor) in order to prevent distortion due to the central tendency of evaluation [113]. In addition to this, the statistical characteristics of the level (mean values) were calculated, namely, the arithmetic mean and median, and evaluation was also performed of the variability of the results using the standard deviation. Differences in the opinions of respondents between different groups according to gender, age, and level of education were analyzed using a Pearson's chi-square test. Differences were tested at the 0.05 level of significance. Statistically significant differences are indicated in bold in the tables.

\section{Results}

The study analyzed and evaluated respondents' attitudes towards 10 statements that were formulated as assertions about the various benefits of the sharing economy in 
three areas of social responsibility and sustainable development, namely, economic, social, and environmental. A four-point Likert scale was used to ascertain the attitudes of the respondents, where the respondents expressed their level of agreement or disagreement with the given claims. The results of the study are evident in Table 5.

Table 5. Attitudes of respondents to the benefits of the sharing economy under investigation.

\begin{tabular}{|c|c|c|c|c|c|c|c|c|c|}
\hline & \multirow{2}{*}{ Statements } & \multicolumn{4}{|c|}{ Score (Frequencies) * } & \multirow{2}{*}{3 and $4(\%)$} & \multirow{2}{*}{ m } & \multirow{2}{*}{$\overline{\mathbf{x}}$} & \multirow{2}{*}{ SD } \\
\hline & & 1 & 2 & 3 & 4 & & & & \\
\hline 1. & The sharing economy is beneficial to the economy of the country. & 55 & 297 & 202 & 60 & 43 & 2 & 2.43 & 0.79 \\
\hline 2. & The sharing economy is a way to ensure more efficient utilization of resources. & 31 & 161 & 318 & 104 & 69 & 3 & 2.81 & 0.77 \\
\hline 3. & Use of services in the sharing economy saves users a significant amount of money. & 21 & 100 & 350 & 143 & 80 & 3 & 3.00 & 0.73 \\
\hline 4. & The sharing economy may be an interesting source of income for providers of assets. & 7 & 67 & 342 & 198 & 88 & 3 & 3.19 & 0.67 \\
\hline 5. & The sharing economy contributes towards a greater level of employment and creates new jobs. & 37 & 232 & 257 & 88 & 56 & 3 & 2.64 & 0.80 \\
\hline 6. & Participation in the sharing economy simplifies the work-life balance. & 28 & 144 & 319 & 123 & 72 & 3 & 2.87 & 0.78 \\
\hline 7. & Use of services in the sharing economy is a source of unusual experiences. & 40 & 165 & 272 & 137 & 67 & 3 & 2.82 & 0.85 \\
\hline 8. & Sharing via platforms saves users time. & 20 & 107 & 331 & 156 & 79 & 3 & 3.01 & 0.75 \\
\hline 9. & Sharing is environmentally friendly thanks to saving resources. & 22 & 107 & 303 & 182 & 79 & 3 & 3.05 & 0.78 \\
\hline 10. & Sharing limits the production of waste. & 27 & 159 & 278 & 150 & 70 & 3 & 2.90 & 0.82 \\
\hline
\end{tabular}

Legend: * Scale: 1 = strongly disagree; $2=$ disagree; $3=$ agree; $4=$ strongly agree; $\mathrm{m}=$ median; $\overline{\mathrm{x}}=$ arithmetic mean; $\mathrm{SD}=$ standard deviation.

It is clear from Table 5 that respondents rated the sharing economy as beneficial in almost all of the 10 aspects under investigation, i.e., in the economic, social, and environmental field. An exception was constituted by the aspect of the benefit of the sharing economy from the point of view of the country's economy. On the contrary, the respondents $(88 \%)$ clearly agreed that the sharing economy could be an interesting source of income for providers of assets. Four-fifths of respondents agreed that use of services in the sharing economy significantly saves money for users. Almost $80 \%$ of respondents agreed that sharing via platforms saves users time and is also environmentally friendly thanks to saving resources. In the context of the evaluation of the benefits of sharing, it should be noted that respondents rated the benefits of a microeconomic nature as more beneficial compared to benefits of a macroeconomic nature.

As is clear from Table 6, the study also ascertained whether benefits in the field of economic, social, and environmental responsibility are perceived as equal, or whether respondents regard benefits in some of the given areas of social responsibility as more important.

Table 6. Attitudes of respondents towards the benefits of the sharing economy in terms of economic, social, and environmental responsibility.

\begin{tabular}{cc}
\hline Area of Benefits of the Sharing Economy & Relative Average Evaluation \\
\hline Economic responsibility & 2.86 \\
\hline Social responsibility & 2.84 \\
\hline Environmental responsibility & 2.98 \\
\hline
\end{tabular}

It is clear from Table 6 that the holistically conceived benefits of the sharing economy were perceived to be almost equivalent in all three areas of social responsibility under investigation.

Comparison was also performed in the study of the attitudes of respondents from the point of view of their gender, age, and level of education. The attitudes of respondents towards the benefits of the sharing economy under investigation from the point of view of men and women are evident in Table 7. 
Table 7. Comparison of the attitudes of respondents towards the benefits of the sharing economy under investigation by gender.

\begin{tabular}{|c|c|c|c|c|c|}
\hline & \multirow[b]{2}{*}{ Statements } & \multicolumn{2}{|c|}{ Relative Frequency } & \multicolumn{2}{|c|}{ Chi-Square Test } \\
\hline & & $\begin{array}{c}\text { Male } \\
3 \text { and } 4(\%)\end{array}$ & $\begin{array}{c}\text { Female } \\
3 \text { and } 4(\%)\end{array}$ & Chi-Square & Sig. \\
\hline 1. & The sharing economy is beneficial to the economy of the country. & 43 & 42 & 0.017 & 0.895 \\
\hline 2. & The sharing economy is a way to ensure more efficient utilization of resources. & 70 & 68 & 0.401 & 0.527 \\
\hline 3. & Use of services in the sharing economy saves users a significant amount of money. & 80 & 80 & 0.007 & 0.933 \\
\hline 4. & The sharing economy may be an interesting source of income for providers of assets. & 88 & 88 & 0.024 & 0.878 \\
\hline 5. & $\begin{array}{l}\text { The sharing economy contributes towards a greater level of employment and } \\
\text { creates new jobs. }\end{array}$ & 53 & 59 & 1.561 & 0.212 \\
\hline 6. & Participation in the sharing economy simplifies the work-life balance. & 72 & 72 & 0.005 & 0.942 \\
\hline 7. & Use of services in the sharing economy is a source of unusual experiences. & 65 & 68 & 0.900 & 0.343 \\
\hline 8. & Sharing via platforms saves users time. & 79 & 80 & 0.020 & 0.888 \\
\hline 9. & Sharing is environmentally friendly thanks to saving resources. & 74 & 83 & 7.551 & 0.006 \\
\hline 10. & Sharing limits the production of waste. & 65 & 74 & 5.336 & 0.021 \\
\hline
\end{tabular}

Legend: Statistically significant differences are indicated in bold.

The survey conducted shows that the attitudes of men and women did not exhibit any statistically significant differences regarding the majority of the benefits of the sharing economy under investigation. Statistically significant differences by the gender of the respondents were only ascertained in two of the investigated benefits in the field of environmental responsibility, when more women agreed with the benefits of sharing in this area than men.

The attitudes of respondents towards the benefits of the sharing economy under investigation from the point of view of the younger generation aged 15 to 29 and the older generation aged 30 or over are evident in Table 8 .

Table 8. Comparison of the attitudes of respondents towards the benefits of the sharing economy under investigation by age.

\begin{tabular}{|c|c|c|c|c|c|}
\hline \multirow{2}{*}{\multicolumn{2}{|c|}{ Statements }} & \multicolumn{2}{|c|}{ Relative Frequency } & \multicolumn{2}{|c|}{ Chi-Square Test } \\
\hline & & $\begin{array}{l}15-29 \text { Years } \\
3 \text { and } 4(\%)\end{array}$ & $\begin{array}{l}30 \text { or More Years Old } \\
3 \text { and } 4(\%)\end{array}$ & Chi-Square & Sig. \\
\hline 1. & The sharing economy is beneficial to the economy of the country. & 41 & 44 & 0.603 & 0.437 \\
\hline 2. & $\begin{array}{l}\text { The sharing economy is a way to ensure more efficient } \\
\text { utilization of resources. }\end{array}$ & 78 & 64 & 13.141 & $<0.0005$ \\
\hline 3. & $\begin{array}{l}\text { Use of services in the sharing economy saves users a significant } \\
\text { amount of money. }\end{array}$ & 81 & 80 & 0.058 & 0.810 \\
\hline 4. & $\begin{array}{l}\text { The sharing economy may be an interesting source of income } \\
\text { for providers of assets. }\end{array}$ & 91 & 86 & 3.246 & 0.072 \\
\hline 5. & $\begin{array}{l}\text { The sharing economy contributes towards a greater level of } \\
\text { employment and creates new jobs. }\end{array}$ & 57 & 56 & 0.130 & 0.718 \\
\hline 6. & $\begin{array}{l}\text { Participation in the sharing economy simplifies the work-life } \\
\text { balance. }\end{array}$ & 79 & 68 & 8.645 & 0.003 \\
\hline 7. & $\begin{array}{l}\text { Use of services in the sharing economy is a source of unusual } \\
\text { experiences. }\end{array}$ & 75 & 62 & 11.156 & 0.001 \\
\hline 8. & Sharing via platforms saves users time. & 80 & 79 & 0.005 & 0.945 \\
\hline 9. & Sharing is environmentally friendly thanks to saving resources. & 85 & 76 & 7.226 & 0.007 \\
\hline 10. & Sharing limits the production of waste. & 74 & 67 & 2.611 & 0.106 \\
\hline
\end{tabular}


It is clear from Table 8 that statistically significantly more members of the younger generation, i.e., respondents aged 15 to 29 , perceived a greater benefit of sharing in the case of four of the 10 aspects under investigation than the older generation aged 30 or more. This specifically concerned benefits in the form of more efficient utilization of resources, simplification of the work-life balance, unusual experiences, and environmental protection thanks to saving resources. In the case of the other benefits of the sharing economy under investigation, no statistically significant differences were confirmed in the attitudes of the younger and older generations.

Comparison of the attitudes of the respondents from the point of view of education is demonstrated in Table 9. A comparison is made here of attitudes expressing agreement with the benefits of sharing under investigation between the group of respondents with primary and secondary education and the group of respondents with higher education.

Table 9. Comparison of the attitudes of respondents towards the benefits of the sharing economy under investigation by education.

\begin{tabular}{|c|c|c|c|c|c|}
\hline & \multirow[b]{2}{*}{ Statements } & \multicolumn{2}{|c|}{ Relative Frequency } & \multicolumn{2}{|c|}{ Chi-Square Test } \\
\hline & & $\begin{array}{c}\text { Primary and } \\
\text { Secondary Education } \\
3 \text { and } 4(\%)\end{array}$ & $\begin{array}{c}\text { Higher } \\
\text { Education } \\
3 \text { and } 4(\%)\end{array}$ & Chi-Square & Sig. \\
\hline 1. & The sharing economy is beneficial to the economy of the country. & 44 & 40 & 0.513 & 0.474 \\
\hline 2. & $\begin{array}{l}\text { The sharing economy is a way to ensure more efficient utilization of } \\
\text { resources. }\end{array}$ & 65 & 80 & 12.399 & $<0.0005$ \\
\hline 3. & $\begin{array}{l}\text { Use of services in the sharing economy saves users a significant } \\
\text { amount of money. }\end{array}$ & 78 & 87 & 5.728 & 0.017 \\
\hline 4. & $\begin{array}{l}\text { The sharing economy may be an interesting source of income for } \\
\text { providers of assets. }\end{array}$ & 87 & 90 & 0.801 & 0.371 \\
\hline 5. & $\begin{array}{l}\text { The sharing economy contributes towards a greater level of } \\
\text { employment and creates new jobs. }\end{array}$ & 57 & 54 & 0.650 & 0.420 \\
\hline 6. & Participation in the sharing economy simplifies the work-life balance. & 72 & 72 & 0.012 & 0.912 \\
\hline 7. & $\begin{array}{l}\text { Use of services in the sharing economy is a source of unusual } \\
\text { experiences. }\end{array}$ & 67 & 67 & 0.000 & 0.987 \\
\hline 8. & Sharing via platforms saves users time. & 79 & 81 & 0.184 & 0.668 \\
\hline 9. & Sharing is environmentally friendly thanks to saving resources. & 78 & 83 & 2.098 & 0.147 \\
\hline 10. & Sharing limits the production of waste. & 69 & 71 & 0.189 & 0.664 \\
\hline
\end{tabular}

Legend: Statistically significant differences are indicated in bold.

It is evident from Table 9 that the attitudes of respondents with different levels of education differed in a statistically significant manner only in two of the 10 aspects. This specifically concerned the benefit of the sharing economy regarding more efficient utilization of resources and saving money for users. In both cases, statistically significantly more respondents with higher education agreed with these benefits than respondents with a lower level of education.

\section{Discussion and Conclusions}

It is evident from the studies that have been performed to date-see, for example, Barnes and Mattsson [80], Geissinger et al. [81], or Leung et al. [4] - that the key motive for sharing is benefit regarding sustainability or social responsibility. The importance of the contribution of sharing towards support for sustainability and social responsibility is also appreciated by the respondents to the survey presented here- the customers from the Czech Republic. That is to say that the study that was performed shows that sharing is beneficial to social responsibility from the point of view of the majority of respondents in all areas - the economic field, the social field, and also the environmental field. Hypothesis H1 (From the point of view of the majority of customers, sharing is a source of benefits not only in 
the field of economic responsibility, but also social and environmental responsibility) was therefore confirmed. Here, an interesting fact is that the investigated respondents did not see any difference in the perception of the benefits of sharing in these areas. The conclusions of Barnes and Mattsson [80], Hallem et al. [79], and Grybaite and Stankevičienè [78] regarding the dominant role of economic responsibility were therefore not confirmed, nor were the conclusions of Geissinger et al. [81] regarding the dominant role of environmental responsibility. On the basis of our findings, we can reject hypothesis $\mathrm{H} 2$ (Customers regard benefits in the field of economic responsibility to be the most important benefits of sharing). However, within the framework of the abovementioned responsibilities-economic, social, and environmental - the respondents always evaluated benefits that were microeconomic in nature in a better light compared to benefits that were macroeconomic in nature. An explanation can be found in the rational choice theory [83] in this case, too.

The study that was performed also shows that the benefits of sharing in terms of economic, social, and environmental responsibility were in most cases viewed equally by men and women. This was the case for eight of the 10 aspects under investigation. Only in the case of environmental benefits were statistically significant differences between men's and women's perceptions confirmed. The benefits of sharing in this area were evaluated as more important by women in comparison to men. Therefore, only in this case were the conclusions of Andreotti et al. [25] confirmed. However, hypothesis H3 (Women perceive the economic, social, and environmental benefits of sharing as more important compared to men) was not confirmed.

The study also shows that the benefits of sharing in terms of economic, social, and environmental responsibility were in most cases viewed equally by the younger and the older generations. This was the case for six of the 10 aspects under investigation. However, in four cases a statistically significant difference was found, with the younger generation perceiving the given benefits of sharing as more important compared to the older generation. In these cases, the conclusions reached by Andreotti et al. [25], Buda et al. [89], and Lindblom A. and Lindblom T. [88] were therefore confirmed. They specifically concerned the benefits of sharing in the form of more efficient utilization of resources, simplification of the work-life balance, unusual experiences, and environmental protection due to saving resources. Hypothesis $\mathrm{H} 4$ (The younger generation perceives the economic, social, and environmental benefits of sharing as more important compared to the older generation) was therefore not confirmed.

The study also shows that the benefits of sharing in terms of economic, social, and environmental responsibility were viewed equally in most cases by respondents with primary and secondary education and by respondents with a higher level of education. This was the case for eight of the 10 aspects under investigation. Only for two aspects of economic responsibility was a statistically significant difference in evaluation proven between respondents with primary and secondary education and respondents with a higher level of education. Respondents with higher education considered the benefits of sharing in the form of efficient use of resources and in the form of financial savings to be more important. Therefore, only in these two cases could an analogy be found with the conclusions drawn by Andreotti et al. [25] and Buda et al. [89]. Hypothesis H5 (People with a higher level of education perceive the economic, social, and environmental benefits of sharing as more important compared to people with a lower level of education) was therefore not confirmed.

The contributions of this article can be seen in both the theoretical and in the practical area. The sharing economy, social responsibility, and sustainable development represent broad concepts that are constantly evolving. The findings presented in this article expand current knowledge by explaining the interconnected nature of these concepts. From the point of view of theoretical knowledge, they further contribute towards expanding knowledge about customer attitudes regarding the perceived benefits of the sharing economy for the economic, social, and environmental fields of social responsibility and, consequently, regarding the ability of the sharing economy to ensure sustainable development, with research having been performed using the example of a small post-communist country. 
Benefits can also be seen in our focus on the users of sharing, as opposed to focusing only on the processes and attitudes of providers. The perceived benefits and attitudes towards use of the sharing economy by users are important to ensure its effective functioning and contribution towards sustainability. From a practical point of view, the findings presented here provide a source of knowledge for the creators of strategy, policy, and tools, with the aim of motivating actual and potential users of sharing and to therefore improve performance in the field of sustainability.

\section{Limitations and Future Research}

As with other studies, the findings of this study should be considered in the light of some limitations. The first is the fact that the study was performed in a small postcommunist economy. Development of the sharing economy in this region, and therefore also the experience of users, may be specific, and when generalizing these results in a wider region, this fact must be taken into consideration and vice versa. The second limitation concerns the methodology used, in terms of which the benefits of the sharing economy were evaluated regardless of the individual segments of sharing, whereas the authors are aware of the fact that different platforms in the sharing economy offer a different benefit for sustainable development, and some are even the subject of discussion and their contribution towards sustainable development is regarded as minimal. In addition to this, characteristics other than those investigated may also have an impact on the benefit of the sharing economy, for example, the standing of users in the sharing economy, i.e., whether they are customers and/or providers, the size of the municipality in which they live, the experience of users with sharing, and the methods with which they use sharing. These factors already reach beyond the framework of the presented study, thereby creating room for further research.

The results of this study can be followed up by other research studies with several different focuses. In the context of the first limitation, it would be possible to further focus on the factors that led to the hypothesis regarding the influence of demographic characteristics on differences in perception of the benefits of the sharing economy compared to those defined by the literature not having been confirmed. Another avenue of research could be the issue of the benefits of the sharing economy at a macroeconomic level, which has been evaluated as beneficial, but less so than at a microeconomic level. Research could also focus on the definition of strategies, policies, and tools that are able to increase the perceived benefit on this level. Finally, in view of the fact that the sharing economy supported by the development of digitization is a quickly growing phenomenon, future research should also be directed towards gaining a more in-depth understanding of the benefits of the sharing economy and its components, be it the forms or processes of sharing towards sustainable development not only in areas defined according to the triple bottom line, but also in relation to meeting the individual SDGs.

Author Contributions: Conceptualization, L.T.; methodology, M.J. and L.T.; formal analysis, M.J., L.T., J.V. and S.M.; investigation, M.J., L.T. and S.M.; resources, M.J., L.T. and J.V.; writing-original draft preparation, M.J., L.T., J.V. and S.M.; writing-review and editing, M.J. and L.T. All authors have read and agreed to the published version of the manuscript.

Funding: This research received no external funding.

Acknowledgments: The paper was supported by the project "Economic, Social and Environmental Aspects of Collaborative Economy from the Point of View of the Czech Republic"; COST Action CA16121 "From Sharing to Caring: Examining Socio-Technical Aspects of the Collaborative Economy".

Conflicts of Interest: The authors declare no conflict of interest.

\section{References}

1. Frenken, K.; Schor, J. Putting the sharing economy into perspective. Environ. Innov. Soc. Trans. 2017, 23, 3-10. [CrossRef]

2. Guyader, H.; Piscicelli, L. Business model diversification in the sharing economy: The case of GoMore. J. Clean. Prod. 2019, 215, 1059-1069. [CrossRef] 
3. Palgan, Y.V.; Zvolska, L.; Mont, O. Sustainability framings of accommodation sharing. Environ. Innov. Soc. Trans. 2017, 23, 70-83. [CrossRef]

4. Leung, X.Y.; Xue, L.; Wen, H. Framing the sharing economy: Toward a sustainable ecosystem. Tour. Manag. 2019, 71, 44-53. [CrossRef]

5. Gerwe, O.; Silva, R. Clarifying the sharing economy: Conceptualization, typology, antecedents, and effects. Acad. Manag. Perspect. 2020, 34, 65-96. [CrossRef]

6. Sutherland, W.; Jarrahi, M.H. The sharing economy and digital platforms: A review and research agenda. Int. J. Inform. Manag. 2018, 43, 328-334. [CrossRef]

7. Parente, R.C.; Geleilate, J.-M.G.; Rong, K. The sharing economy globalization phenomenon: A research agenda. J. Internat. Manag. 2018, 24, 52-64. [CrossRef]

8. Pei, J.; Yan, P.; Kumar, S.; Liu, X. How to react to internal and external sharing in B2C and C2C. Prod. Oper. Manag. 2020, 30, 145-170. [CrossRef]

9. Grondys, K. Implementation of the sharing economy in the B2B sector. Sustainability 2019, 11, 3976. [CrossRef]

10. Tetrevova, L.; Vlckova, V. Benefits, limitations and measures concerning the development of cooperation between higher education institutions and external entities. Tert. Educ. Manag. 2018, 24, 377-394. [CrossRef]

11. Klievink, B.; Janssen, M.; van der Voort, H.; van Engelenburg, S. Regulatory compliance and over-compliant information sharing-Changes in the B2G landscape. In Proceedings of the International Conference on Electronic Government, Krems, Austria, 3-5 September 2018; Lecture Notes in Computer Science. Springer: Cham, Switzerland, 2018; Volume 11020, pp. 249-260. [CrossRef]

12. Tetrevova, L. Options for use of charitable sharing for protection of public health during the COVID-19 pandemic-Experience from the Czech Republic. Pub. Adm. Soc. 2020, 21, 21-32.

13. Martin, C.J.; Upham, P.; Budd, L. Commercial orientation in grassroots social innovation: Insights from the sharing economy. Ecol. Econ. 2015, 118, 240-251. [CrossRef]

14. Schor, J.B.; Cansoy, M. The sharing economy. In The Oxford Handbook of Consumption; Wherry, F.F., Woodward, I., Eds.; Oxford University Press: Oxford, UK, 2019; pp. 51-74.

15. Gossen, M.; Pentzien, J.; Peuckert, J. What use is it really for sustainability? Potentials and impacts of peer-to-peer sharing in the domains of accommodation and mobility. Sustain. Manag. Forum. 2019, 27, 125-138. [CrossRef]

16. Habibi, M.R. The progression and impact of the sharing economy; a preface. J. Mark. Theory Pract. 2019, 27, 349-354. [CrossRef]

17. Eurobarometer. The Use of the Collaborative Economy. Available online: https://data.europa.eu/euodp/en/data/dataset/S218 4_467_ENG (accessed on 24 October 2020).

18. Heinrichs, H. Sharing economy: A potential new pathway to sustainability. GAIA-Ecol. Perspect. Sci. Soc. 2013, 22, 228-231. [CrossRef]

19. Elkington, J. Towards the sustainable corporation: Win-win-win business strategies for sustainable development. Calif. Manag. Rev. 1994, 36, 90-100. [CrossRef]

20. Longoni, A.; Cagliano, R. Sustainable innovativeness and the triple bottom line: The role of organizational time perspective. J. Bus. Ethics 2018, 151, 1097-1120. [CrossRef]

21. Tetrevova, L. Communicating CSR in high profile industries: Case study of Czech chemical industry. Inz. Ekon. 2018, 29, 478-487. [CrossRef]

22. Buchholz, T.; Luzadis, V.A.; Volk, T.A. Sustainability criteria for bioenergy systems: Results from an expert survey. J. Clean. Prod. 2009, 17, S86-S98. [CrossRef]

23. Szczuka, M. Social dimension of sustainability in CSR standards. Procedia Manuf. 2015, 3, 4800-4807. [CrossRef]

24. Tetrevova, L.; Kolmasova, P. Possibilities of the sharing economy from the point of view of chemical companies. Chem. Listy 2021, $115,280-285$.

25. Andreotti, A.; Anselmi, G.; Eichhorn, T.; Hoffmann, C.P.; Jürss, S.; Micheli, M. Participation in the sharing economy: European Perspectives. SSRN Electron. J. 2017. [CrossRef]

26. Klarin, T. The Concept of sustainable development: From its beginning to the contemporary issues. Zagreb Int. Rev. Econ. Bus. 2018, 21, 67-94. [CrossRef]

27. United Nations. Report of the World Commission on Environment and Development: Our Common Future. Available online: File:/ / /D:/Data/lite1020/Stazene/our_common_futurebrundtlandreport1987.pdf (accessed on 29 October 2020).

28. United Nations. United Nations Millennium Declaration. Available online: http://www.un.org/millennium/declaration/ares5 52e.htm (accessed on 28 May 2021).

29. Kapitan, S.; Bhargave, R.; Trask, K.; Sundie, M.J.; Silvera, H.D. Product End-of-Life Decisions. In Communicating Sustainability for the Green Economy, 1st ed.; Kahle, L.R., Gurel-Atay, E., Eds.; Routledge: New York, NY, USA, 2015; pp. 52-68.

30. Ritter, M.; Schanz, H. The sharing economy: A comprehensive business model framework. J. Clean. Prod. 2019, 213, 320-331. [CrossRef]

31. Magee, L.; Scerri, A.; James, P.; Thom, J.A.; Padgham, L.; Hickmott, S.; Deng, H.; Cahill, F. Reframing social sustainability reporting: Towards an engaged approach. Environ. Dev. Sustain. 2013, 15, 225-243. [CrossRef]

32. United Nations. Agenda 21: Earth Summit-The United Nations Programme of Action from Rio. Available online: https: // sustainabledevelopment.un.org/outcomedocuments/agenda21 (accessed on 5 May 2021). 
33. United Nations. Indicators of Sustainable Development: Framework and Methodologies. Available online: https://sdgs.un.org/ publications /indicators-sustainable-development-guidelines-and-methodologies-2nd-edition-16992 (accessed on 14 May 2021).

34. United Nations. Description of CSD indicators of sustainable development. In Indicators of Sustainable Development, 1st ed.; United Nations: Geneva, Switzerland, 2013; pp. 47-99. [CrossRef]

35. United Nations. The 17 Goals. Available online: https://sdgs.un.org/goals (accessed on 29 October 2020).

36. Sachs, J.D.; Schmidt-Traub, G.; Mazzucato, M.; Messner, D.; Nakicenovic, N.; Rockström, J. Six transformations to achieve the Sustainable Development Goals. Nat. Sustain. 2019, 2, 805-814. [CrossRef]

37. Rosen, M. How can we achieve the UN Sustainable Development Goals? Eur. J. Sustain. Dev. Res. 2017, 1, 1-4. [CrossRef]

38. Kamruzzaman, P. A critical note on poverty eradication target of Sustainable Development Goals. Eur. J. Sustain. Dev. 2016, 5, 87-110. [CrossRef]

39. Koehler, G. Tapping the Sustainable Development Goals for progressive gender equity and equality policy? Gend. Dev. 2016, 24, 53-68. [CrossRef]

40. Kanbur, R. Sustainable Development Goals and the study of economic inequality. J. Econ. Inequal. 2020, 19, 3-11. [CrossRef]

41. Činčalová, S.; Hedija, V. Firm characteristics and corporate social responsibility: The case of Czech transportation and storage industry. Sustainability 2020, 12, 1992. [CrossRef]

42. Sterling, S. A Commentary on education and Sustainable Development Goals. J. Educ. Sustain. Dev. 2016, 10, 208-213. [CrossRef]

43. Wulf, C. Peace-Violence, Alterity, Sustainable Development. SSRN Electron. J. 2020. [CrossRef]

44. MacNaughton, G.; Frey, D.F. Decent Work, Human Rights and the Sustainable Development Goals. Georget. J. Int. Law 2016, 47, 1-57. [CrossRef]

45. Činčalová, S. Inequalities in social responsibility across Europe focused on work-life balance. Calitatea 2020, $21,142-146$.

46. Bexell, M.; Jönsson, K. Responsibility and the United Nations' Sustainable Development Goals. Forum Dev. Stud. 2016, 44, 13-29. [CrossRef]

47. Ebner, D.; Baumgartner, R.J. The Relationship between Sustainable Development and Corporate Social Responsibility. In Proceedings of the Corporate Responsibility Research Conference 2006, Dublin, Ireland, 4-5 September 2006.

48. Thakkar, F.M. Sustainable development through corporate social responsibility and corporate sustainability. World Wide J. Multidiscip. Res. Develop. 2017, 3, 83-85.

49. Bowen, H.R. Social Responsibilities of the Businessman, 1st ed.; Harper \& Row: New York, NY, USA, 1953.

50. Carroll, A.B. Corporate social responsibility. Bus. Soc. 1999, 38, 268-295. [CrossRef]

51. Nejati, M.; Shafaei, A.; Salamzadeh, Y.; Daraei, M. Corporate social responsibility and universities: A study of top 10 world universities' websites. Afr. J. Bus. Manag. 2011, 5, 440-447. [CrossRef]

52. García-Sánchez, I.M.; Frías-Aceituno, J.V.; Rodríguez-Domínguez, L. Determinants of corporate social disclosure in Spanish local governments. J. Clean. Prod. 2013, 39, 60-72. [CrossRef]

53. Tetrevova, L.; Jelinkova, M. Municipal social responsibility of statutory cities in the Czech Republic. Sustainability 2019, 11, 2308. [CrossRef]

54. Sánchez-Hernández, M.I.; Aguilar-Yuste, M.; Maldonado-Briegas, J.J.; Seco-González, J.; Barriuso-Iglesias, C.; Galán-Ladero, M.M. Modelling Municipal Social Responsibility: A Pilot Study in the Region of Extremadura (Spain). Sustainability 2020, 12, 6887. [CrossRef]

55. Kouatli, I. The contemporary definition of university social responsibility with quantifiable sustainability. Soc. Resp. J. 2019, 15, 888-909. [CrossRef]

56. Meseguer-Sánchez, V.; Abad-Segura, E.; Belmonte-Ureña, L.J.; Molina-Moreno, V. Examining the research evolution on the socio-economic and environmental dimensions on university social responsibility. Int. J. Environ. Res. Public Health 2020, 17, 4729. [CrossRef] [PubMed]

57. Tetrevova, L.; Vavra, J.; Munzarova, S. Communication of socially-responsible activities by higher education institutions. Sustainability 2021, 13, 483. [CrossRef]

58. Friedman, M. The social responsibility of business is to increase its profits. The New York Times Magazine, 13 September 1970; Volume 33, pp. 122-126.

59. Andersen, B. Bringing Business Ethics to Life: Achieving Corporate Social Responsibility, 1st ed.; ASQ, Quality Press: Milwaukee, WI, USA, 2004.

60. Moratis, L.T.; Cochius, T. ISO 26000: The Business Guide to the New Standard on Social Responsibility, 1st ed.; Greenleaf Publishing: Sheffield, UK, 2011.

61. ISO. ISO 26000 and SDGs. Available online: https:/ / www.iso.org/publication/PUB100401.html (accessed on 30 March 2021).

62. Hahn, T.; Preuss, L.; Pinkse, J.; Figge, F. Cognitive frames in corporate sustainability: Managerial sensemaking with paradoxical and business case frame. Acad. Manag. Rev. 2014, 39, 463-487. [CrossRef]

63. Jiang, W.; Wong, J.K.W. Key activity areas of corporate social responsibility (CSR) in the construction industry: A study of China. J. Clean. Prod. 2016, 113, 850-860. [CrossRef]

64. Tetrevova, L. Communication of socially responsible activities by sugar-producing companies. Listy Cukrov. 2017, 133, 394-396.

65. Habibi, R.; Davidson, A.; Larocheb, M. What managers should know about the sharing economy. Bus Horiz. 2017, 60, 113-121. [CrossRef] 
66. Schlagwein, D.; Schoder, D.; Spindeldreher, K. Consolidated, systemic conceptualization, and definition of the "sharing economy". J. Assoc. Inf. Sci. Technol. 2019, 71, 817-838. [CrossRef]

67. Huarng, K.H. Entrepreneurship for long-term care in sharing economy. Int. Entrep. Manag. J. 2018, 14, 97-104. [CrossRef]

68. Oh, S.; Moon, J.Y. Calling for a Shared Understanding of the Sharing Economy. In Proceedings of the 18th Annual International Conference on Electronic Commerce: E-Commerce in Smart Connected World (ICEC 2016), Suwon, Korea, 17-19 August 2016. [CrossRef]

69. Ungeman, O.; Dědková, J. Model of the circular economy and its application in business practice. Environ. Dev. Sustain. 2020, 22, 3407-3432. [CrossRef]

70. Gurau, C.; Ranchhod, A. The sharing economy as a complex dynamic system: Exploring coexisting constituencies, interests and practices. J. Clean. Prod. 2020, 245, 118799. [CrossRef]

71. Hossain, M. Sharing economy: A comprehensive literature review. Int. J. Hosp. Manag. 2020, 87, 102470. [CrossRef]

72. Sinthupundaja, J.; Kohda, Y. Effects of corporate social responsibility and creating shared value on sustainability. Int. J. Sust. Entrep. CSR 2017, 2, 27-38. [CrossRef]

73. Etter, M.; Fieseler, C.; Whelan, G. Sharing economy, sharing responsibility? Corporate social responsibility in the digital age. J. Bus. Ethics 2019, 159, 935-942. [CrossRef]

74. Acquier, A.; Daudigeos, T.; Pinkse, J. Promises and paradoxes of the sharing economy: An organizing framework. Technol. Forecast. Soc. 2017, 125, 1-10. [CrossRef]

75. Hamari, J.; Sjöklint, M.; Ukkonen, A. The sharing economy: Why people participate in collaborative consumption. J. Assoc. Inf. Sci. Technol. 2015, 67, 2047-2059. [CrossRef]

76. Joo, J.H. Motives for participating in sharing economy: Intentions to use car sharing services. J. Distrib. Sci. 2017, 15, 21-26. [CrossRef]

77. Wilhelms, M.P.; Henkel, S.; Falk, T. To earn is not enough: A means-end analysis to uncover peer-providers' participation motives in peer-to-peer carsharing. Technol. Forecast. Soc. 2017, 125, 38-47. [CrossRef]

78. Grybaitè, V.; Stankevičienè, J. Motives for participation in the sharing economy-evidence from Lithuania. Ekon. Zarz. 2016, 8, 7-17. [CrossRef]

79. Hallem, Y.; Ben Arfi, W.; Teulon, F. Exploring consumer attitudes to online collaborative consumption: A typology of collaborative consumer profiles. Can. J. Admin. Sci. 2020, 37, 82-94. [CrossRef]

80. Barnes, S.J.; Mattsson, J. Understanding current and future issues in collaborative consumption: A four-stage Delphi study. Technol. Forecast. Soc. 2016, 104, 200-211. [CrossRef]

81. Geissinger, A.; Laurell, C.; Öberg, C.; Sandström, C. How sustainable is the sharing economy? On the sustainability connotations of sharing economy platforms. J. Clean. Prod. 2019, 206, 419-429. [CrossRef]

82. Ipsos. Available online: https://www.ipsos.com/cs-cz/spolecenska-odpovednost-firem-roste-tlak-na-ferove-chovani-kzamestnancum (accessed on 22 April 2020).

83. Piscicelli, L.; Cooper, T.; Fisher, T. The role of values in collaborative consumption: Insights from a product-service system for lending and borrowing in the UK. J. Clean. Prod. 2015, 97, 21-29. [CrossRef]

84. Kuzey, C.; Uyar, A. Determinants of sustainability reporting and its impact on firm value: Evidence from the emerging market of Turkey. J. Clean. Prod. 2017, 143, 27-39. [CrossRef]

85. Tetrevova, L.; Patak, M.; Kyrylenko, I. Web-based CSR communication in post-communist countries. Appl. Econ. Lett. 2019, 26, 866-871. [CrossRef]

86. Tetrevova, L.; Patak, M.; Kyrylenko, I. CSR web communication in controversial industries: The example of chemical companies based in post-communist countries. J. Promot. Manag. 2020, 27, 562-584. [CrossRef]

87. Ipsos. Available online: https://www.ipsos.com/sites/default/files/ct/news/documents/2018-04/tz_ceska_asociace_sdilene_ ekonomiky_ipsos_12.4.2018.pdf (accessed on 12 April 2018).

88. Lindblom, A.; Lindblom, T. De-ownership orientation and collaborative consumption during turbulent economic times. Int. J. Consum. Stud. 2017, 41, 431-438. [CrossRef]

89. Buda, G.; Pethes, B.; Lehota, J. Dominant consumer attitudes in the sharing economy-A representative study in Hungary. Resources 2019, 9, 1. [CrossRef]

90. Soběhart, R. Sharing economy regulation in the Czech Republic: The theoretical framework of analysis. Littera Scr. 2018, 11, 106-115.

91. Weichbroth, P. Usability of mobile applications: A systematic literature study. IEEE Access 2020, 8, 55563-55577. [CrossRef]

92. Pluye, P.; Hong, Q.N.; Bush, P.L.; Vedel, I. Opening-up the definition of systematic literature review: The plurality of worldviews, methodologies and methods for reviews and syntheses. J. Clin. Epidemiol. 2016, 73, 2-5. [CrossRef] [PubMed]

93. Wohlin, C. Guidelines for Snowballing in Systematic Literature Studies and a Replication in Software Engineering. In Proceedings of the 18th International Conference on Evaluation and Assessment in Software Engineering-EASE'14, London, UK, 13-14 May 2014. [CrossRef]

94. Wohlin, C. Second-generation Systematic Literature Studies Using Snowballing. In Proceedings of the 20th International Conference on Evaluation and Assessment in Software Engineering-EASE'16, Limerick, Ireland, 1-3 June 2016. [CrossRef]

95. Mamaphala, M.M.; Cassim, N.; Karodia, A.M. The impact of change management on the implementation of organisational strategy: A case study of national home builders registration council. Singap. J. Econ. Manag. Stud. 2016, 5, 1-39. [CrossRef] 
96. Owens, L.K. Introduction to Survey Research Design, 1st ed.; Survey Research Laboratory: Chicago, IL, USA, 2002.

97. Taylor, J.Z.; Rostron, K.I. The development of a safety and quality culture assessment tool from a longitudinal, mixed-method research journey. Worldw. Hosp. Tour. Them. 2018, 10, 313-329. [CrossRef]

98. Harrison, L. Quantitative designs and statistical analysis. In Doing Early Childhood Research: International Perspectives on Theory and Practice; Routledge: New York, NY, USA, 2020.

99. Tetrevova, L.; Patak, M. Web-based communication of socially responsible activities by gambling operators. J. Gambl. Stud. 2019, 35, 1441-1455. [CrossRef] [PubMed]

100. Parzonko, A.J.; Balińska, A.; Sieczko, A. Pro-Environmental Behaviors of Generation Z in the Context of the Concept of Homo Socio-Oeconomicus. Energies 2021, 14, 1597. [CrossRef]

101. Klein, M.; Gutowski, P.; Gerlitz, L. Creative and Culture Industry in Baltic Sea Region Condition and Future. Sustainability 2021, 13, 4239. [CrossRef]

102. Tomaselli, V.; Battiato, S.; Ortis, A.; Cantone, G.G.; Urso, S.; Polosa, R. Methods, Developments, and Technological Innovations for Population Surveys. Soc. Sci. Comput. Rev. 2021, 089443932199421. [CrossRef]

103. Czarniecka-Skubina, E.; Pielak, M.; Sałek, P.; Korzeniowska-Ginter, R.; Owczarek, T. Consumer Choices and Habits Related to Coffee Consumption by Poles. Int. J. Environ. Res. Public Health 2021, 18, 3948. [CrossRef]

104. Choy, L.T. The Strengths and Weaknesses of Research Methodology: Comparison and Complimentary between Qualitative and Quantitative Approaches. IOSR J. Humanist Soc. Sci. 2014, 19, 99-104. [CrossRef]

105. Lysenko-Ryba, K.; Zimon, D. Customer Behavioral Reactions to Negative Experiences during the Product Return. Sustainability 2021, 13, 448. [CrossRef]

106. Novotova, J. Exploring customer loyalty to fashion brands on facebook fan pages. E M Ekon. Manag. 2018, 21, 206-223. [CrossRef]

107. Ratajczak, A.; Badyda, A.; Czechowski, P.O.; Czarnecki, A.; Dubrawski, M.; Feleszko, W. Air Pollution Increases the Incidence of Upper Respiratory Tract Symptoms among Polish Children. J. Clin. Med. 2021, 10, 2150. [CrossRef]

108. Etikan, I.; Musa, S.A.; Alkassim, R.S. Comparison of Convenience Sampling and Purposive Sampling. Am. J. Theor. Appl. Stat. 2016, 5, 1-4. [CrossRef]

109. Chakrapani, C. Marketing Research: State-of-the-Art Perspectives, 1st ed.; American Marketing Association: Chicago, IL, USA, 2000.

110. Rada, V.D.; Martín, V.M. Random Route and Quota Sampling: Do They Offer Any Advantage over Probably Sampling Methods? Open J. Stat. 2014, 4, 391-401. [CrossRef]

111. Poon, K.Y.; Huang, W.J. Past experience, traveler personality and tripographics on intention to use Airbnb. Int. J. Contemp. Hosp. Manag. 2017, 29, 2425-2443. [CrossRef]

112. Tahal, R. Basic Methods of Primary Data Collection in Marketing Research, 1st ed.; C.H.Beck: Prague, Czech Republic, 2015. (In Czech)

113. Croasmun, J.T.; Ostrom, L. Using Likert-Type Scales in the Social Sciences. J. Adult Educ. 2011, 40, 19-22. 